Section: Animal Science

Research article

\title{
Ruminal kinetics and degradability of energetic feedstuffs used in diets for ruminants
}

\section{Degradabilidade e cinética ruminal de alimentos energéticos utilizados em dietas para ruminantes}

Mikael Neumann ${ }^{1}$ (D), Leslei Caroline Santos ${ }^{1}$ (D), Eloize Jaqueline Askel ${ }^{2 *}$ (D), Bruno José Venancio $^{1}$ (D) , Giovanna Bobato Pontarolo ${ }^{1}$ (D) , Fernando Braga Cristo ${ }^{1}$ (D) , Daniel Corrêa Plodoviski ${ }^{1}$ (i) , Emylli Pereira e Silva ${ }^{1}$ (D)

${ }^{1}$ Universidade Estadual do Centro-Oeste (UNICENTRO), Guarapuava, PR, Brazil

2Univesidade Federal do Paraná (UFPR), Curitiba, PR, Brazil

*Correspondent: elojaque@gmail.com

Received

May 19, 2021.

Accepted

October 4, 2021.

Published

November 12, de 2021.

www.revistas.ufg.br/vet visit the website to get the how to cite in the article page.

\begin{abstract}
This study aimed to evaluate energetic feedstuffs regarding chemical composition, in situ ruminal degradability of dry matter (DMD), ruminal kinetics and ruminal disappearance rate of dry matter. Seven feedstuffs (treatments) were evaluated: ground corn, ground oat, ground barley, wheat bran, soybean hull, malt root and corn germ, in a completely randomized design of four repetitions each. Two bovines ruminally cannulated were used for incubation, wherein each treatment was subjected to seven periods of exposure to the rumen $(0,3$, $6,9,12,18$ and 24 hours). Among the evaluated feedstuffs, soybean hull had the highest neutral detergent fiber (NDF) content (68.91\%) and the lowest DMD at $24 \mathrm{~h}$ (64.91\%). Ground barley and ground corn contained the lowest content of soluble fraction (SF) (26.34 and 28.7\%, respectively), among which ground barley had the highest DMD at $24 \mathrm{~h}(90.48 \%)$ and therefore showed the highest rumen disappearance rate $\left(2.50 \% . \mathrm{h}^{-1}\right)$ by combining both parameters, while the ground oat presented the highest SF (47.75\%) and the lowest rumen disappearance rate $\left(1.09 \% \cdot \mathrm{h}^{-1}\right)$.
\end{abstract}

Key words: chemical composition; grains and industrial derivatives; ruminal disappearance rate

\section{Resumo \\ Objetivou-se neste trabalho avaliar alimentos energéticos quanto a composição química, degradabilidade ruminal in situ da matéria seca (DMS), cinética ruminal e taxa de desaparecimento ruminal da matéria seca. Foram avaliados sete alimentos (tratamentos): grão de milho moído, grão de aveia moído, grão de cevada moído, farelo de trigo, casca de soja, radícula de malte e gérmen de milho, num delineamento inteiramente casualizado com quatro repetições cada. Para a incubação dos materiais foram utilizados dois bovinos com}


cânula ruminal, e cada tratamento foi submetido a sete períodos de exposição ao rúmen $(0,3,6,9,12,18$ e 24 horas). Dentre os alimentos avaliados, a casca de soja teve o maior teor de fibra em detergente neutro (68,91\%) e apresentou a menor DMS em 24 h (64,91\%). O grão de cevada moído e o grão de milho moído tiveram os menores níveis de fração solúvel (FS) (26,34\% e $28,7 \%$, respectivamente), porém o grão de cevada moído apresentou a maior DMS em 24 h (90,48\%), que por conciliar estes parâmetros teve a maior taxa de desaparecimento ruminal (2,50\%.h-1), enquanto o grão de aveia moído teve a maior FS $(47,75 \%)$ e a menor taxa de desaparecimento ruminal (1,09\%.h-1).

Palavras-chave: composição química; grãos e derivados industriais; taxa de desaparecimento ruminal

\section{Introduction}

In ruminant nutrition, the mixture of feedstuffs that favor the synchronicity of carbohydrate and protein degradation in the rumen maximizes microbial efficiency, decreases nitrogen losses as ammonia and carbohydrate energy losses, and this represents the maximization of the use of nutrients and animal performance ${ }^{(1)}$. Thus, it is necessary to know the proportions of feedstuff fractions and the nutrient degradation rates $^{(2)}$.

For ruminants, availability and degradability of nutrients can be determined using in situ, in vitro and in vivo techniques(3). The nylon bag ruminal incubation technique (in $\mathrm{situ}^{(4)}$ is the most frequently used to determine the ruminal degradability of components such as dry matter and crude protein, and is used as a reference method for evaluating ruminal degradation of feedstuffs ${ }^{(5)}$.

Starch is the main energy source of most cereal grains such as corn, sorghum, barley, wheat and oats. For ruminants, starch is an important energy source for microbial growth, but in some situations it is desirable to control the inclusion and ruminal digestibility of $\operatorname{starch}^{(6)}$.

In this context, industrial derivatives represent an alternative to replace starchy ingredients, as they have fast fermenting carbohydrates, with high quality fiber (highly degradable). These feedstuffs are low in starch and high in neutral detergent fiber (NDF), and often contain other components such as soluble carbohydrates and/or pectin(7). An example is soybean hull and malt root, both with high fiber and low starch content, being an option for inclusion in ruminant diets, when the diet has high grain and starch content ${ }^{(8)}$. It is a fiber that degrades rapidly in the rumen and is a good source of energy ${ }^{(9)}$ and modulator of rumen health.

Thus, knowledge of feedstuff fractions and nutrient degradation rates is used to balance ruminant diets ${ }^{(2)}$. In this context, this study aimed to evaluate the rates of ruminal degradation of energy feedstuffs and tested the hypothesis that cereal grains have greater ruminal degradability at 24 hours when compared to industrial derivatives. For this, we evaluated the chemical composition, dry matter ruminal 
disappearance rate and ruminal disappearance rate of dry matter from cereal grains (ground corn, ground oat and ground barley) and industrial derivatives (wheat bran, soybean hull, malt root and corn germ) used in ruminant nutrition.

\section{Material and methods}

The experiment was conducted by Núcleo de Produção Animal (NUPRAN) at Universidade Estadual do Centro-Oeste (UNICENTRO), located in Guarapuava, state of Paraná. The experimental procedures were approved by Comissão de Ética no Uso de Animais (CEUA/UNICENTRO) under document 011/2019.

Seven energetic feedstuffs were evaluated, regarding chemical composition, ruminal kinetics, ruminal disappearance rate of dry matter and in situ ruminal degradability of dry matter (DMD). The analyzed feedstuffs were cereal grains (ground corn, ground oat, ground barley) and industrial derivatives (wheat bran, soybean hull, malt root and corn germ).

Feedstuffs were weighed and pre-dried in a forced air oven at $55^{\circ} \mathrm{C}$ for 72 hours. Then they were ground in a Wiley mill, with a $1 \mathrm{~mm}$ mesh sieve(10). Subsequently, total dry matter (DM) was determined in an oven at $105^{\circ} \mathrm{C}$ (AOAC, 1995, method 930:15), crude protein (CP) by the micro Kjeldahl method (AOAC, 1995, method 984:13), ashes by incineration at $550^{\circ} \mathrm{C}$ (4 hours) (AOAC, 1995, method 942:05) and fat (AOAC, 1995, method 920:39). Neutral detergent fiber (NDF) content was determined using thermostable a-amylase ${ }^{(11)}$. The content of non-fiber carbohydrates (NFC) was obtained by the equation $[N F C, \%=100-(a s h+C P+$ fat + NDF)]. Table 1 lists data on the chemical composition of the evaluated energy feedstuffs before incubation.

Table 1. Chemical composition of feedstuffs

\begin{tabular}{rcccccc}
\hline Items & $\begin{array}{c}\text { DM } \\
\text { g/kg NM }\end{array}$ & Ash & Fat & $\begin{array}{c}\text { CP } \\
\text { \% DM }\end{array}$ & NDF & NFC \\
\hline Ground corn & 910 & 1.14 & 3.57 & 8.22 & 12.86 & 74.21 \\
Ground oat & 913 & 1.99 & 3.18 & 11.11 & 27.15 & 56.58 \\
\hline Ground barley & 912 & 1.97 & 1.25 & 11.15 & 16.04 & 69.59 \\
\hline Wheat bran & 935 & 4.26 & 3.41 & 15.45 & 42.47 & 34.41 \\
\hline Soybean hull & 934 & 3.97 & 2.59 & 11.76 & 68.91 & 12.77 \\
\hline Malt root & 943 & 4.53 & 1.12 & 15.39 & 43.97 & 34.99 \\
\hline Corn germ & 929 & 3.90 & 11.81 & 10.15 & 34.46 & 39.68 \\
\hline
\end{tabular}

$\mathrm{CP}=$ crude protein; $\mathrm{DM}$ = dry matter; NDF = neutral detergent fiber; NFC = non-fiber carbohydrates; NM $=$ natural matter.

To determine the in situ ruminal degradability of feedstuffs, two Jersey castrated male cattle, with an average weight of $750 \mathrm{~kg}$ and fistulated in the rumen were used. Animals were adapted to a diet of 50\% corn silage and 50\% concentrate, and housed in a pen 
with access to an exclusive paddock. Food was provided twice a day, and water was available in a trough regulated by an automatic buoy.

For rumen incubation, the pre-dried and ground ingredients, in the amount of $5 \mathrm{~g}$, were packed in nylon bags of known weight $(10 \mathrm{~cm} \times 12 \mathrm{~cm}$, with a $50 \mu \mathrm{m}$ porosity). The bags were sealed and attached to a nylon thread with a lead weight (100 g) at the end ${ }^{(9)}$.

Ruminal incubation was performed by introducing the bags in both animals simultaneously, following the decreasing order of the pre-established times. The first incubated samples were those that remained for 24 hours in the rumen, following the order of $18,12,9,6,3$ and 0.08 hours. The samples at time 0.08 hours remained incubated for 5 minutes before removing all bags. Immediately after removal, samples were immersed in iced water for 20 minutes, to disrupt rumen microbial activity. Then, bags were washed, dried in a forced air oven at $55^{\circ} \mathrm{C}$ for 72 hours and weighed. Thus, the results regarding in situ ruminal degradability were obtained ${ }^{(10)}$. The evaluations of the treatments in the seven incubation times, with four repetitions were made in duplicates.

The DM ruminal disappearance rate was evaluated by the difference in weight of the pre- and post-incubated material at different times. Estimates of kinetic parameters for DM were performed as proposed by Ørskov and McDonald(4): where PD = a + b (1-e-ct); in which PD is the potential ruminal degradability of feedstuff; "a" the soluble fraction (SF) corresponding to 0 hours of incubation; " $b$ " is the potentially degradable fraction in the rumen (PDFR) corresponding to 24 hours of incubation by subtracting the fraction "a"; and "c" the non-degradable fraction in the rumen (NDFR) (100 - value degraded in 24 hours) $)^{(10)}$.

The experimental design was completely randomized, consisting of seven treatments and four replications. Data were tested by analysis of variance (ANOVA) and then, when a difference was detected, the Tukey's test for comparison of multiple means was applied at a 5\% significance level, using the SAS statistical software (1993). Data of dry matter ruminal disappearance rate were calculated for Proc Reg regression analysis of the SAS statistical software (1993).

\section{Results and discussion}

Among the feedstuffs evaluated, cereal grains have the lowest content of NDF (Table 1) and the highest content of NFC and, therefore, are used to increase the energy and starch content of diets. As for the NDF content, among these feedstuffs, the ground oat had the highest NDF content. Prates et al.(12) evaluated two oat varieties, and found higher values of NDF and acid detergent fiber (ADF) in relation to barley grain. These differences in fiber content are due to the proportion of hull and grain between the cereals, with oats having a higher proportion of hulls. The hull is formed by cellulose, hemicellulose, arabinoxylan, polyphenols and phytonutrients, and a higher proportion of hull generates a higher NDF content and, among whole grains, the proportion of hull is variable (20 to $30 \%)^{(12)}$.

Industrial derivatives (soybean hull, corn germ, wheat bran and malt root) showed high NDF content $(68.91,34.46,42.47$ and $43.97 \%)$, with soybean hull being the feedstuff 
with the highest NDF content (68.91\%), a value similar to other studies $(13,14,15)$.

Corn germ contains a higher fat content. And it is obtained from the corn grain germination, where the endosperm is separated from the germ and pericarp during grinding, Corn germ constitutes 30\% total volume of corn processed, and can be used as defatted germ (1\% of fat) or as whole germ, which was evaluated in the present study. Whole germ can be obtained by wet or dry milling. In the latter, corn is subjected to cleaning and grinding in an impact or attrition mill, separating the germ, the pericarp and the endosperm tip. The germ from dry milling contains lower lipid content (approximately 13\%) compared to wet milling (50\%), and is intended for animal feed ${ }^{(16,}$ 17).

The evaluated feedstuffs contained low protein content. Among them, wheat bran and malt root had higher CP content (average of $15.42 \%$ ), similar CP values were found in the literature for wheat bran ${ }^{(18)}$, which has high degradability protein, and compared to cereal grains, it has a low starch content (around 31.3\%)(19).

The malt root evaluated in this study was obtained from the malt production process for beer brewing, by forced germination of barley grains, when the shoots and radicles are removed, including or not hulls and other parts of the grain. Malt root showed one of the highest contents of CP (15.39\%) and NDF (43.97\%).

The ground barley showed the highest ruminal degradability $(P<0.05)$ at 12 and 24 hours of incubation, and the highest potentially degradable fraction in the rumen (Table 2). And soybean hull had the lowest ruminal degradability $(\mathrm{P}<0.05)$ at 12 and 24 hours, with values of 37.95 and $64.91 \%$, respectively. The ground oat presented the highest soluble fraction $(47.75 \%)$ and the lowest potentially degradable fraction in the rumen (28.94\%).

Table 2. In situ ruminal degradability of dry matter (DMD) at 12 and 24 hours of ruminal incubation, soluble fraction (SF), potentially degradable fraction in the rumen (PDFR), non-degradable fraction in the rumen (NDFR) of different energetic feedstuffs

\begin{tabular}{rccccc}
\hline \multirow{2}{*}{ Items } & DMD 12 h & DMD 24 h & SF & PDFR & NDFR \\
\cline { 2 - 6 } & \multicolumn{5}{c}{ (\% dry matter) } \\
\hline Ground corn & $57.94^{\mathrm{c}}$ & $76^{\mathrm{c}}$ & $28.7^{\mathrm{d}}$ & $47.3^{\mathrm{b}}$ & $24^{\mathrm{b}}$ \\
Ground oat & $72.8^{\mathrm{b}}$ & $76.69^{\mathrm{c}}$ & $47.75^{\mathrm{a}}$ & $28.94^{\mathrm{e}}$ & $23.31^{\mathrm{b}}$ \\
Ground barley & $78.97^{\mathrm{a}}$ & $90.48^{\mathrm{a}}$ & $26.34^{\mathrm{d}}$ & $64.14^{\mathrm{a}}$ & $9.52^{\mathrm{d}}$ \\
Wheat bran & $69.23^{\mathrm{b}}$ & $74.93^{\mathrm{c}}$ & $36.87^{\mathrm{c}}$ & $38.06^{\mathrm{c}}$ & $25.07^{\mathrm{b}}$ \\
Soybean hull & $37.95^{\mathrm{d}}$ & $64.91^{\mathrm{d}}$ & $19.35^{\mathrm{e}}$ & $45.56^{\mathrm{b}}$ & $35.09^{\mathrm{a}}$ \\
\hline Malt root & $63.46^{\mathrm{bc}}$ & $73.33^{\mathrm{c}}$ & $39.38^{\mathrm{b}}$ & $33.95^{\mathrm{d}}$ & $26.67^{\mathrm{b}}$ \\
\hline Corn germ & $66.24^{\mathrm{bc}}$ & $81.44^{\mathrm{b}}$ & $41.85^{\mathrm{b}}$ & $39.59^{\mathrm{c}}$ & $18.56^{\mathrm{c}}$ \\
\hline
\end{tabular}

Means followed by different lowercase letters in the same column differ from each other by Tukey's test $(\mathrm{P}<0.05)$. 
The highest DMD at $24 \mathrm{~h}$ was found for ground barley, which also had the highest disappearance rate $\left(2.49 \% . \mathrm{h}^{-1}\right)$, with PDFR of $64.14 \%$, while ground corn and ground oat presented lower values. Characteristically, corn grains have a stronger protein matrix around starch granules than other cereals, which hinders the action of digestive enzymes and amylolytic bacteria, which interferes with ruminal degradability ${ }^{(6)}$. And ground oat have a higher proportion of hull compared to ground barley, so the DMD at $24 \mathrm{~h}$ and the NDFR were lower, corroborating literature data ${ }^{(12)}$, which also point to a lower digestible fraction for grain oat varieties compared to grain barley.

For greater ruminal degradability and nutrient availability of cereal grains, it is necessary to consider the grinding particle size, and reduce the particle size and increase the specific surface of the feed. Particularly in corn, the grain contains $65-80 \%$ starch in its composition, and has a considerable protein matrix, with the whole grain showing a pericarp resistant to digestion, in this case, the processing increases the use of the grain ${ }^{(20)}$. Considering corn grinding to $1 \mathrm{~mm}$, in the present experiment, a 24-hour DMD of $76 \%$ was observed.

Other feedstuffs are slowly released into the rumen, such as soybean hull, which after 24 hours of incubation had 45.56\% FPDR and 35.09\% FNDR. Despite high NDF values in soybean hull, the fiber fraction is highly digestible ${ }^{(15)}$ because there is a thin film rich in pectin, and soybean hull have $30 \%$ soluble carbohydrates, providing high digestibility, as verified by Silva et al. ${ }^{(14)}$ in the in vitro digestibility of NDF, which was $85.65 \%$, and in in vitro digestibility of $\mathrm{DM}, 76.88 \%$.

High values of soluble fraction were obtained for feedstuffs evaluated in this experiment (ranging from $19.35 \%$ to $47.75 \%$ for soybean hull and ground oat, respectively), with an average of 34.32\%, higher than verified in other studies analyzing this same parameter. Some notes can be made regarding the methodology, Goes et al.(2), for example, evaluated sunflower, soybean and crambe grains, and the average of the soluble fraction was $17.71 \%$, lower than in the present study. However, grinding for ruminal incubation was done at $5 \mathrm{~mm}$. Thus, the particle size was larger, which explains the lower soluble fraction, since the finer grinding and formation of smaller particles facilitate the solubilization of the sample. The difference in the soluble fraction between feedstuffs may be due to the hydration capacity of the source ${ }^{(13)}$. Thus, the particle size influences degradability or digestibility ${ }^{(15)}$. This because we observed a DMD at $24 \mathrm{~h}$ of $64.91 \%$ with a $1 \mathrm{~mm}$ particle size, while Zambom et al.(15) obtained a DMD of 54.35\% with a $5 \mathrm{~mm}$ particle size.

And considering the ruminal degradability of energy feedstuffs, ground barley was degraded faster than ground corn. In this sense, in diet formulation, a higher level of non-fiber carbohydrates can be included when ruminal digestibility of energy feedstuffs is low (soybean hull, wheat bran, for example), while lower concentrations of non-fiber carbohydrates should be included when there is participation of wet corn, oats or finely ground barley in the diet (21). Because these feedstuffs have high ruminal degradation. Ground barley contains a low soluble fraction, and a high ruminal disappearance rate of dry matter (Figure 1).

Ground oat presented the greatest initial ruminal disappearance $(55.07 \%)$, with a degradation rate of $1.08 \% \cdot \mathrm{h}^{-1}$ (Figure 1 ). Wheat bran had the second greatest initial disappearance, with $45.66 \%$, with a degradation rate of $1.47 \% \cdot \mathrm{h}^{-1}$. The lowest values of 
initial disappearance were verified for soybean hull (16.90\%) and corn grain (27.17\%), while ground barley had the highest ruminal degradation rate $\left(2.49 \% \cdot \mathrm{h}^{-1}\right)$ among the evaluated feedstuffs. The soybean hull degradation rate was $1.98 \% . \mathrm{h}^{-1}$, considering the period of $24 \mathrm{~h}$, while Silva et al.(14) found a lower degradation rate for soybean hull $\left(0.07 \% . \mathrm{h}^{-1}\right)$, but the incubation period was longer (maximum value of $120 \mathrm{~h}$ ). Possibly, the period considered was longer, which generated a lower degradation rate per hour, while the degradation rate in $24 \mathrm{~h}$ was more accentuated for concentrate feed.

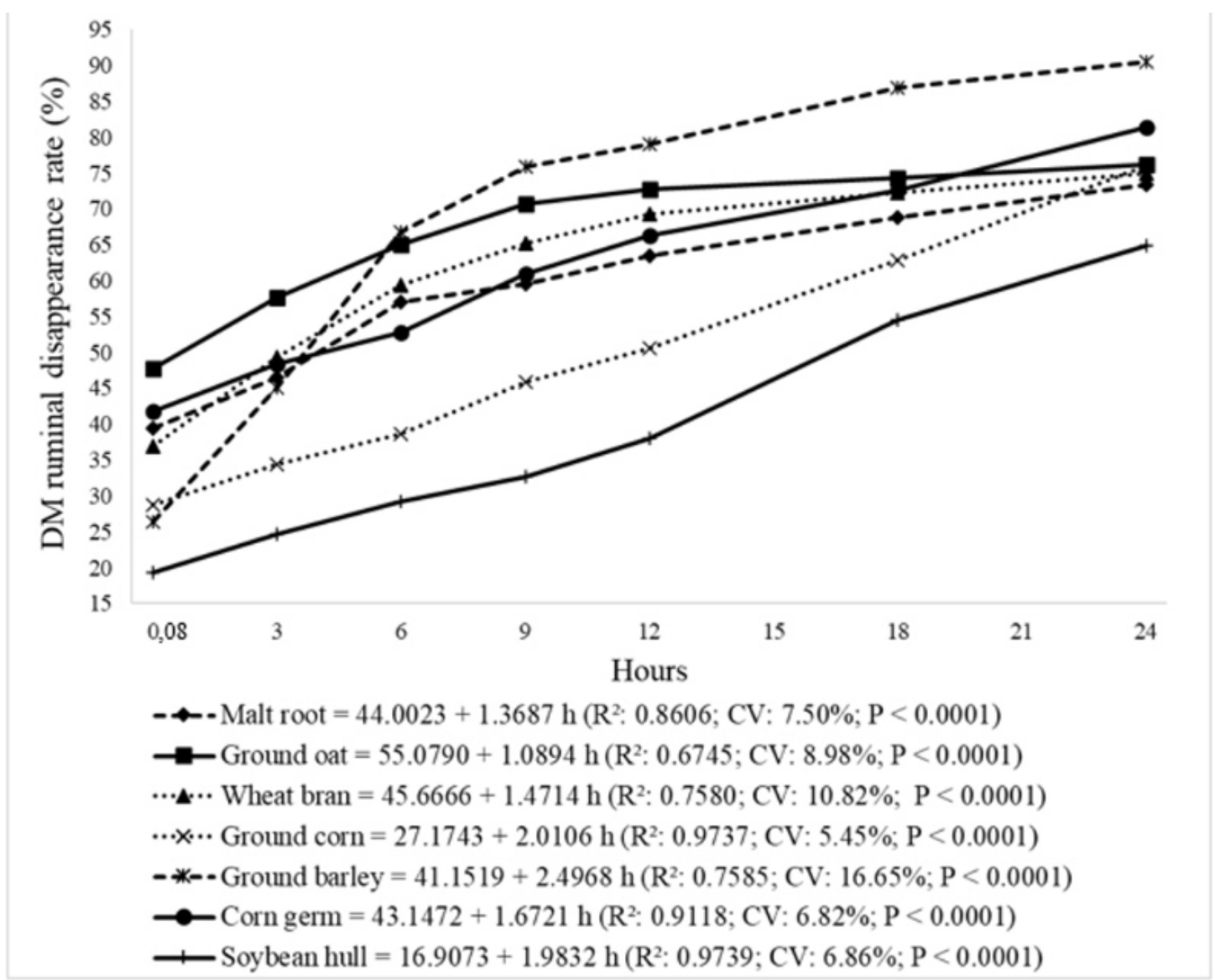

Figure 1. Dry matter (DM) ruminal disappearance rate $\left(\% \cdot \mathrm{h}^{-1}\right)$ of different energy feedstuffs

Starchy ingredients, which combine a high fraction "a" (soluble) with a high content of NFC, such as ground oat, or those with a high dry matter ruminal disappearance rate, such as ground corn and ground barley, combined with high content of NFC, should be moderately included in ruminant diet. In this case, the use of industrial derivatives with a lower dry matter ruminal disappearance rate favors the fermentation profile and rumen health.

When industrial derivatives partially replace grains in ruminant diets, the acetate content tends to increase and the propionate content to decrease due to the fermentation profile, but without impairing the productive performance. In the study 
by Bernard and McNeill(22), the partial replacement of ground corn with soybean hull was $25 \%$ (in a diet of approximately $16 \%$ CP) and did not alter the milk and fat production of Holstein cows. In the study of Ranathunga et al.(23), the starch content decreased in the diet by replacing ground corn with dry distillers grains with solubles and soybean hull did not affect milk yield and components. Xu et al. ${ }^{(17)}$ also verified that the replacement of forages with dry distillers grains with solubles and corn germ in diets with similar NDF and total digestible nutrients did not alter the growth, rumen development and apparent nutrient digestibility of Holstein calves after weaning.

In addition, NDF from industrial derivatives, such as soybean hull, does not limit dry matter intake, such as forage $\operatorname{NDF}^{(24)}$. And soybean hull contains higher potentially degradable NDF than most forages, which can contribute to an increase in the rate of passage ${ }^{(25)}$.

\section{Conclusions}

Among the cereal grains evaluated, ground barley was the feedstuff with the highest degradability at 24 hours, while ground corn and ground oat showed lower ruminal degradability and slower rates, probably due to their chemical composition; corn, for example, due to protein matrix around starch granules. Corn germ, malt root and wheat bran, despite their higher fiber content, showed good ruminal degradation kinetics, indicating that, despite the low NFC content, they have components that can be used by ruminants.

\section{Interest conflicts}

The authors declare no conflicts of interest.

\section{References}

1. Alves, E.M.; Pedreira, M.S.; Oliveira, C.A.S.; Ferreira, D.N.; Moreira, B.S.; Freire, L.D.R. Importância da sincronização do complexo proteína/energia na alimentação de ruminantes. Pubvet. 2010 Maio; 4(20): 844-849. Available from: $\quad$ https://www.pubvet.com.br/artigo/2265/importacircncia-dasincronizaccedilatildeo-do-complexo-proteiacutenaenergia-na-alimentaccedilatildeo-de-ruminantes

2. Goes R H T B, Souza K A, Patussi R A, Cornelio T C, Oliveira E R, Brabes K C S. Degradabilidade in situ dos grãos de crambe, girassol e soja, e de seus coprodutos em ovinos. Acta Scientiarum. 2010 Sep; 32(3): 271277. Available from: http://dx.doi.org/10.4025/actascianimsci.v32i3.7913.

3. Habib G, Khan N A, Ali M, Bezabih M. In situ ruminal crude protein degradability of by-products from cereals, oilseeds and animal origin. Livestock Science. 2013 May; 153(1-3): 81-87. Available from: https:// doi.org/10.1016/j.livsci.2013.01.017

4. Ørskov E R, McDonald I. The estimation of protein degradability in the rumen from incubation measurements weighted according to rate of passage. Journal of Agricultural Science. 1979 Apr; 92(1): 499-508. Available from: https://doi.org/10.1017/S0021859600063048

5. National Research Council. Nutrient requirements of dairy cattle. Washington: National Research Council, 2001, 356p.

6. Nocek J E, Tamminga S. Site of digestion of starch in the gastrointestinal tract of dairy cows and its 
Ruminal kinetics and degradability of energetic feedstuffs used in diets for ruminants Neummann M et al.

effect on milk and composition. Journal of Dairy Science. 1991 Oct; 74(10): 3598-3607. Available from: https://doi.org/10.3168/jds.S0022-0302(91)78552-4

7. Sutton J D. Altering milk composition by feeding. Journal of Dairy Science. 1989 Oct; 72(10): 2801-2814. Disponível em: https://doi.org/10.3168/jds.S0022-0302(89)79426-1

8. López M C, Estellés F, Moya V J, Fernández C. Use of dry citrus pulp or soybean hulls as a replacement for corn grain in energy and nitrogen partitioning, methane emissions, and milk performance in lactating Murciano-Granadina goats. Journal of Dairy Science. 2014 Dec; 97(12): 7821-7832. Available from: https:I /doi.org/10.3168/jds.2014-8424

9. Cunnigham K D, Cecava M J, Johnson T R. Nutrient digestion, nitrogen and amino acid flows in lactating cows fed soybean hulls in place of forage or concentrate. Journal of Dairy Science. 1993 Nov; 76(11): 3523-3535. Available from: https://doi.org/10.3168/jds.S0022-0302(93)77691-2

10. Neumann M, Askel E J, Santos L C, Stadler Junior E S, Venancio B J, Pontarolo G B, Cristo F B, Silva E P. Evaluation of degradability and ruminal kinetics of soybean meal subjected to strategies to maximize protein escape from the rumen. Semina: Ciências Agrárias. 2020 Nov/Dez; 41(6): 2721-2732. Available from: https://10.5433/1679-0359.2020v41n6p2721

11. Van Soest P J, Roberttson J B, Lewis B A. Methods for dietary fiber, neutral detergent fiber and non starch polysaccharides in relation to animal nutrition. Journal of Dairy Science. 1991 Oct; 74(10): 3583-3597. Available from: https://doi.org/10.3168/jds.S0022-0302(91)78551-2

12. Prates $L L$, Refat $B$, Lei $Y$, Louzada-Prates $M$, Yu P. Relationship of carbohydrates and lignin molecular structure spectral profiles to nutrient profile in newly developed oats cultivars and barley grain. Spectrochimica Acta Part A: Molecular and Biomolecular Spectroscopy. 2018 Jan; 188: 485-506. Available from: https://doi.org/10.1016/j.saa.2017.07.042

13. Goes R H T B, Tramontini R C, Almeida G D, Cardim S T, Ribeiro J, Oliveira L A, Morotti F, Brabes K C S, Oliveira E R. Degradabilidade ruminal da matéria seca e proteína bruta de diferentes subprodutos agroindustriais utilizados na alimentação de bovinos. Revista Brasileira de Saúde e Produção Animal. 2008 Oct/Dec; 9(3): 715-725. Available from: http://revistas.ufba.br/index.php/rbspa/article/view/ 945/694.

14. Silva D C, Kazama R, Faustino J O, Zambom M A, Santos G T, Branco A F. Digestibilidade "in vitro" e degradabilidade "in situ" da casca do grão de soja, residuo de soja e casca de algodão. Acta Scientiarum. Animal Sciences. 2004 Apr; 26(4): 501-506. Available from: http://dx.doi.org/10.4025/ actascianimsci.v26i4.1733

15. Zambom M A, Santos G T, Modesto E C, Alcalde C R, Gonçalves G D, Silva D C, Silva K T, Faustino J O. Valor nutricional da casca do grão de soja, farelo de soja, milho moído e farelo de trigo para bovinos. Acta Scientiarum. 2001; 23(4): 937-943. Available from: http://dx.doi.org/10.4025/actascianimsci.v23i0.2648

16. Moreau R A, Johnston D B, Hicks K B. The influence of moisture content and cooking on the screw pressing and prepressing of corn oil from corn germ. Journal of the American Oil Chemist Society. 2005 Nov; 82(11): 851-854. Available from: https://aocs.onlinelibrary.wiley.com/doi/epdf/10.1007/ s11746-005-1154-6

17. Xu J, Hou Y, Zhao G, Yu A, Su Y, Huo Y, Zhu J. Replacement of forage fiber sources with dried distillers grains with solubles and corn germ meal in Holstein calf diets. Journal of Integrative Agriculture. 2014 Aug; 13(8): 1753-1758. Available from: https://doi.org/10.1016/S2095-3119(13)60602-4

18. Sari M, Ferret B, Calsamiglia S. Effect of $\mathrm{pH}$ on in vitro microbial fermentation and nutrient flow in diets containing barley straw or non-forage fiber sources. Animal Feed Science and Technology. 2015 Feb; 200: 17-24. Available from: https://doi.org/10.1016/j.anifeedsci.2014.11.011

19. Pereira E M, Santos F A P, Bittar C M M, Ramalho T R, Costa D F A, Martinez J C. Substituição do milho 
por farelo de trigo ou farelo de glúten de milho na ração de bovinos de corte em terminação. Acta Scientiarum Animal Sciences. 2007 Nov; 29(1): 49-55. Available from: https://doi.org/10.4025/ actascianimsci.v29i1.251

20. Mourão R C, Pancoti C G, Moura A M, Ferreira A L, Borges A L C C, Silva R R. Processamento do milho na alimentação de ruminantes. Pubvet. 2012 Feb; 6(5): 1289-1294. Available from: https:// www.pubvet.com.br/artigo/3051/processamento-do-milho-na-alimentaccedilatildeo-de-ruminantes

21. Stone W C. Nutritional approaches to minimize subacute ruminal acidosis and laminitis in dairy cattle. Journal of Dairy Science. 2004 Jul; 87: E13-E26. Available from: https://doi.org/10.3168/ jds.S0022-0302(04)70057-0

22. Bernard K, McNeill W W. Effect of high fiber energy supplements on nutrient digestibility and milk production of lactating dairy cows. Journal of Dairy Science. 1991 Mar; 74(3): 991-995. Available from: https://doi.org/10.3168/jds.S0022-0302(91)78248-9

23. Ranathunga S D, Kalscheur K F, Hippen A R, Schingoethe D J. Replacement of starch from corn with nonforage fiber from distillers grains and soyhulls in diets of lactating dairy cows. Journal of Dairy Science. 2010 Mar; 93(3): 1086-1097. Available from: https://doi.org/10.3168/jds.2009-2332

24. Karlsson J, Lindberg M, Akerlind M, Holtenius K. Whole-lactation feed intake, milk yield, and energy balance of Holstein and Swedish Red dairy cows fed grass-clover silage and 2 levels of byproduct-based concentrate. Journal of Dairy Science. 2020 Oct; 103(10): 8922-8937. Available from: https://doi.org/ 10.3168/jds.2020-18204

25. Ipharraguerre I R, Clark J H. Soyhulls as an alternative feed for lactating dairy cows: A review. Journal of Dairy Science. 2003 Apr; 86(4): 1052-1073. Available from: https://doi.org/10.3168/ jds.S0022-0302(03)73689-3 